\title{
ОБГРУНТУВАННЯ ЗНАЧЕННЯ ВЕБ-ПОРТАЛУ НАВЧАЛЬНО-МЕТОДИЧНИХ МАТЕРІАЛІВ ДЛЯ ТЕОРЕТИЧНОЇ ТА ПРАКТИЧНОЇ ПІДГОТОВКИ СТУДЕНТІВ-СТОМАТОЛОГІВ
}

\author{
Тернопільський державний медичний університет імені І. Я. Горбачевського \\ У роботі обґрунтовується ефективність використання Веб-порталу навчально-методичних матеріалів в теоре- \\ тичній та практичній підготовці студентів-стоматологів. \\ Ключові слова: веб-портал, електронні документи, мультимедіа, медична освіта.

\section{ОБОСНОВАНИЕ ЗНАЧЕНИЯ ВЭБ-ПОРТАЛА УЧЕБНО-МЕТОДИЧЕСКИХ МАТЕРИАЛОВ ДЛЯ ТЕОРЕТИЧЕСКОЙ И ПРАКТИЧЕСКОЙ ПОДГОТОВКИ СТУДЕНТОВ-СТОМАТОЛОГОВ}

О. А. Стаханская

Тернопольский государственный медицинский университет имени И. Я. Горбачевского

В работе обосновывается эффективность использования Вэб-портала учебно-методических материалов в теоретической и практической подготовке студентов-стоматологов.

Ключевые слова: вэб-портал, электронные документы, мультимедиа, медицинское образование.

\section{ARGUMENTATION OF IMPORTANCE OF WEB-PORTAL OF EDUCATIONAL AND METHODICAL RESOURCES FOR THEORETICAL AND PRACTICAL TRAINING OF STOMATOLOGICAL STUDENTS}

\author{
O. O. Stakhanska
}

Ternopil State Medical University by I. Ya. Horbachevsky

\begin{abstract}
In this work we substantiate the efficiency of application of Web-portal of educational resources for theoretical and practical training of stomatological students.
\end{abstract}

Key words: Web- portal, electronic resources, multimedia, medical education.

Вступ. Інтеграція у світовий медичний освітній простір вимагає розробки новітніх навчальних інформаційних ресурсів. Такі ресурси пережили кілька технологічних стадій розвитку. Досить згадати, що ще до 2000-х, така інформація, як правило, розміщувалася на СБ-, а потім на БУБ-дисках. Її̈ перегляд передбачав інсталяцію в комп'ютер спеціальних програм. Перший такий мультимедійний СБ-диск в Україні був випущений в 1997 році видавництвом «Укрмедкнига» [1].

3 початку 2000-х років з появою швидкісних каналів Інтернет, що дозволили передачу відео, створюються Веб-портали медичних навчальних матеріалів. Одним з перших такий Веб-портал було створено в Терно- пільському державному медичному університеті, на цьому порталі сьогодні представлено понад 23 тисячі навчально-методичних матеріалів, включаючи матеріали для підготовки до лекцій та практичних занять, навчальні відеофільми та відеозаписи практичних навичок, електронні версії підручників та посібників видавництва «Укрмедкнига» [2-4].

Мета даної роботи - дослідити ефективність використання студентами-стоматологами Веб-порталу навчально-методичних матеріалів для теоретичної та практичної підготовки.

Матеріал та методи дослідження. Для оцінки рівня знань та практичних навичок студентів-стоматологів в 2006/07 та 2007/08 навчальних роках в 
Тернопільському державному медичному університеті проведено експериментальні курси 3 дитячої стоматології для 259 студентів-стоматологів. На першому етапі було встановлено ступінь Інтернетобізнаності. Більшість студентів добре володіла Інтернет-технологіями (рис. 1).

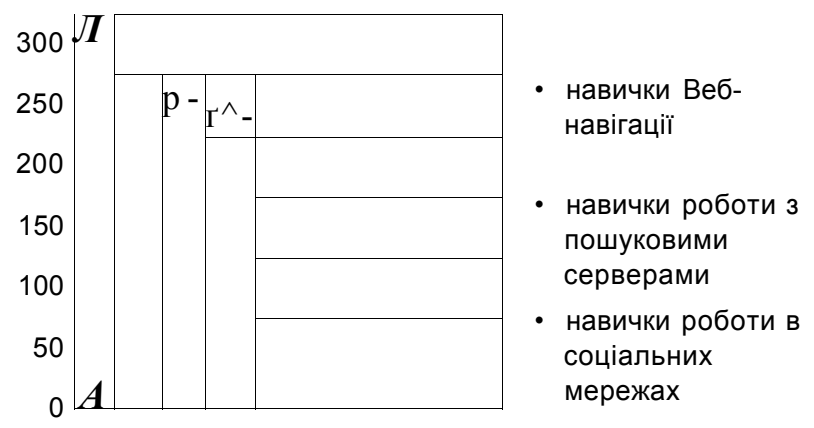

Puc.1. Володіння Інтернет-технологіями.

Середній вік студентів був 21 рік, кількість осіб жіночої статі складала 52 \%. На другому етапі було проведене рандомізоване дослідження щодо зіставлення ефективності використання в навчальному процесі Веб-порталу навчально-методичних матеріалів. Студентів поділили на дві групи: дослідну (142 студенти 2007/08 н.р.) та контрольну (117 студентів 2006/07 н.р.).

Студенти контрольної групи опановували курс в звичайному форматі, а дослідної - той самий курс, отримавши доступ до мультимедійних матеріалів для тдготовки до лекцій та практичних занять, розміщених на Веб-порталі університету з авторизованим доступом.

3 метою перевірки ефективності Веб-порталу навчально-методичних матеріалів для опанування теоретичних знань було використано семестровий тестовий іспит з дитячої стоматології (48 завдань, включаючи тести 3 короткими відповідями, запитання до графічних зображень та ситуаційні задачі).

В якості інструменту визначення впливу Веб-порталу на рівень практичних навичок студентів використано стандартизовану методику ОСКІ (Об'єктивний структурований клінічний іспит), впроваджену в ТДМУ на основі досвіду співпраці 3 університетом Південної Кароліни (США) і яка передбачає проходження студентом 12-ти робочих станцій. На кожній з таких станцій студент демонструє виконання навичок з хірургічної, терапевтичної та ортопедичної стоматології.

Здійснили порівняння результатів тестового іспиту для перевірки ефективності Веб-порталу навчальнометодичних матеріалів для опанування теоретичних знань. Отримані результати наведені в таблиці 1.

Здійснені порівняння результатів іспиту ОСКІ 3 метою визначення ефективності мультимедійних навчально-методичних матеріалів Веб-порталу для опанування практичних навичок. Отримані результати наведені в таблиці 2.

Таблиця 1. Зіставлення позитивних відповідей залежно від виду тестових завдань

\begin{tabular}{|c|c|c|c|c|c|c|c|}
\hline \multirow[b]{2}{*}{ Вид завдання } & \multirow[b]{2}{*}{$\begin{array}{c}\text { Кількість } \\
\text { завдань }\end{array}$} & \multicolumn{3}{|c|}{ Контрольна група, 117 студентів } & \multicolumn{3}{|c|}{ Основна група, 142 студенти } \\
\hline & & $\begin{array}{c}\text { заг. } \\
\text { к-сть } \\
\text { завдань }\end{array}$ & $\begin{array}{c}\text { к-сть } \\
\text { позит. } \\
\text { від., абс. }\end{array}$ & $\begin{array}{c}\text { к-сть } \\
\text { позит. від., } \\
\%\end{array}$ & $\begin{array}{c}\text { заг. } \\
\text { к-сть } \\
\text { завдань }\end{array}$ & $\begin{array}{c}\text { к-сть } \\
\text { позит. } \\
\text { від., абс. }\end{array}$ & $\begin{array}{l}\text { к-сть } \\
\text { позит. } \\
\text { від., \% }\end{array}$ \\
\hline $\begin{array}{l}\text { з відкритими короткими } \\
\text { відповідями }\end{array}$ & 32 & 3744 & 2576 & 68,8 & 4544 & 2985 & 65,7 \\
\hline з графічними ображеннями & 12 & 1404 & 650 & 46,3 & 1704 & 931 & 54,6 \\
\hline у вигляді ситуаційних задач & 4 & 468 & 152 & 32,5 & 568 & 198 & 34,8 \\
\hline
\end{tabular}

Таблиця 2. Зіставлення результатів ОСКІ залежно від стоматологічної дисципліни (кількість станцій - 12)

\begin{tabular}{|c|c|c|c|c|c|c|c|}
\hline \multirow[b]{2}{*}{ Вид завдання } & \multirow[b]{2}{*}{$\begin{array}{l}\text { Кількість } \\
\text { завдань }\end{array}$} & \multicolumn{3}{|c|}{$\begin{array}{c}\text { Контрольна група, } \\
117 \text { студентів }\end{array}$} & \multicolumn{3}{|c|}{$\begin{array}{c}\text { Основна група, } \\
142 \text { студенти }\end{array}$} \\
\hline & & $\begin{array}{l}\text { заг. к-сть } \\
\text { спроб }\end{array}$ & $\begin{array}{c}\text { к-сть } \\
\text { позит. } \\
\text { спроб, } \\
\text { абс. }\end{array}$ & $\begin{array}{l}\text { к-сть поз. } \\
\text { спроб, \% }\end{array}$ & $\begin{array}{c}\text { заг. } \\
\text { к-ть } \\
\text { спроб }\end{array}$ & $\begin{array}{c}\text { к-сть } \\
\text { позит. } \\
\text { спроб, } \\
\text { абс. }\end{array}$ & $\begin{array}{c}\text { к-сть } \\
\text { поз. } \\
\text { спроб, } \\
\%\end{array}$ \\
\hline Хірургічна стоматологія & 3 & 351 & 269 & 76,64 & 426 & 376 & 88,26 \\
\hline Терапевтична стоматологія & 3 & 351 & 312 & 88,89 & 426 & 392 & 92,02 \\
\hline Дитяча стоматологія & 3 & 351 & 298 & 84,9 & 426 & 387 & 90,85 \\
\hline Ортопедична стоматологія & 3 & 351 & 258 & 73,5 & 426 & 323 & 75,68 \\
\hline
\end{tabular}

Після завершення курсу також було здійснене спеціальне анонімне анкетування з метою оцінки ефек- тивності використання навчально-методичних ресурсів Веб-порталу на основі відповідей студентів. 
Анкети включали в себе питання про Інтернет-обізнаність студентів, а також ступінь ефективності навчального процесу за рядом показників.
Нижче наведено результати відповідей на основі запитання щодо загальної характеристики навчального курсу (табл. 3).

Таблиця 3.

\begin{tabular}{|c|c|c|c|c|c|}
\hline \multirow[t]{2}{*}{ Питання анкети } & \multicolumn{2}{|c|}{$\begin{array}{c}\text { Ствердна відповідь } \\
\text { Контрольна група, } 117 \\
\text { студентів } \\
\end{array}$} & \multicolumn{2}{|c|}{$\begin{array}{c}\text { Ствердна відповідь } \\
\text { Основна група, } \\
142 \text { студенти } \\
\end{array}$} & \multirow[t]{2}{*}{ Критерій $\mathrm{P}$} \\
\hline & $\begin{array}{l}\text { абс. } \\
\text { кількість }\end{array}$ & $\%$ & $\begin{array}{c}\text { абс. } \\
\text { кількість }\end{array}$ & $\%$ & \\
\hline Чи складним був матеріал курсу & 82 & 70,1 & 91 & 64,1 & $>0,05$ \\
\hline $\begin{array}{l}\text { Чи отримали Ви міцні знання } 3 \\
\text { даного курсу }\end{array}$ & 71 & 60,68 & 112 & 78,87 & $<0,05$ \\
\hline $\begin{array}{l}\text { Чи отримали Ви ефективні } \\
\text { практичні навички } 3 \text { даного курсу }\end{array}$ & 95 & 81,2 & 124 & 87,32 & $>0,05$ \\
\hline $\begin{array}{l}\text { Чи достатньо сучасною була } \\
\text { інформація, викладена в навчально- } \\
\text { методичних матеріалах курсу }\end{array}$ & 56 & 47,86 & 109 & 76,76 & $<0,05$ \\
\hline $\begin{array}{l}\text { Чи повною мірою виклад курсу } \\
\text { супроводжувався демонстрацією } \\
\text { практичних навичок }\end{array}$ & 63 & 53,85 & 115 & 80,98 & $<0,05$ \\
\hline $\begin{array}{l}\text { Чи оперативним був у Вас доступ до } \\
\text { сучасних інформаційних джерел } 3 \\
\text { даного курсу }\end{array}$ & 83 & 70,94 & 121 & 85,21 & $<0,05$ \\
\hline
\end{tabular}

Як видно з наведеної таблиці, для значної кількості студентів обох груп матеріал курсу був складним. Відповідний довірчий інтервал складав $(70,1 \pm 8,9) \%$ у контрольній та $(64,1 \pm 7,5) \%$ в основній групі. Підкреслимо, що статистично достовірних розходжень між дослідною та контрольною групами тут не виявлено ( $>00,05)$. Це ж стосується, на жаль, і ефективності здобутих практичних навичок. Хоча спостерігається певне кількісне зростання у ствердних відповідях, таке збільшення не є статистично достовірним. Водночас, на усі інші запитання отримано відповіді, які свідчать про достовірні зміни в сторону покращення засвоєння знань при використанні Веб-порталу навчально-методичних матеріалів. Особливо такі зміни є значущими, коли йдеться про сучасність наданого матеріалу при опануванні курсу, про демонстрування усіх необхідних практичних навичок, про доступ до оперативної інформації.

\section{Лiтература}

1. Компакт диск «Лапароскопічні операції та маніпуляції жовчних шляхів». Автори: Л.Я.Ковальчук, О.Л.Ковальчук, Ю.М.Спіженко і ін. - Тернопіль : Укрмедкнига, 1997.

2. Ковальчук Л. Я. Комп'ютерні технології в медичній освіті / Л. Я. Ковальчук, В. П. Марценюк // Медична інформатика та інженерія. - №> 1. - 2008. - С. 14-16.

3. Марценюк В. П. Розробка і впровадження системи електронного навчання в Тернопільському державному ме-
Висновки. Аналіз результатів ефективності використання Веб-порталу навчально-методичних матеріалів для студентів-стоматологів свідчить про його суттєве значення для організації навчального процесу на сучасному етапі.

1. Насамперед слід відзначити оперативність і новизну представленої для студентів інформації, порівняно $з$ традиційними підручниками і посібниками, на написання та друкування яких йде багато часу.

2. Також важливим є наповнення Веб-порталу мультимедійними ресурсами, такими як відеозаписи практичних навичок, операцій та маніпуляцій, аудіозаписи тонів серця та інших внутрішніх органів тощо.

3. Веб-портал навчально-методичних матеріалів може збагатити процес навчання, роблячи його більш ефективним. Слід взяти до уваги й те, що використання електронних навчальних матеріалів зменшує витрати на організацію навчального процесу.

дичному університеті імені І. Я. Горбачевського / В. П. Марценюк // Медична освіта. - №9 2. - 2008. - С. 74-75. 4. Марценюк В. П., Гураль С. Я., Коцюба Р. Б., Стаханська О. О. Комп'ютерна програма «Інформаційна система ^^еьпублікації навчально-методичних матеріалів в медичній освіті (ЩЕВМЕБЕБЦ)». Свідоцтво про реєстрацію авторського права на твір №>39803 від 29.08.2011. 